\title{
IS THE MAGNETIZED SEA-WATER COULD ACT AS ANEW ALTERNATIVE ACARICIDE?
}

\author{
A. M. Hussein, Ghada E. Abdalla, Mariam G. Habishy, Amal E.Marouf \\ and M.H. Mahgoub \\ Plant Protection Research Institute, Agricultural Research Center, Dokki, Cairo, Egypt
}

Received: Mar. 11, 2017

Accepted: Apr. 11, 2017

\begin{abstract}
In lab-experiment lasted from March 2015 to January 2016 to declare the effect of static magnetism on the biology and potentiality to compact the phytophagous mites Tetranychus urticae (Tetranychidae), a total numbers of 2410 mite individuals (with 3 replicates), were reared on plant discs (caster bean) under laboratory temperature. Discs were dipped on 6 treatments of solutions as the following: 1-Distilled water, (control or check), (w). 2magnetized distilled water (W+mag). 3- Sea water(s), 4- magnetized sea water (S+mag). 5Vertimec solution (the recommended acaricide), (V) and 6- magnetized vertimec solution ( $V+$ mag).

Investigation and recording results was carried out 1,3 and 5 days after treatments. Results reported that there was a clear and significant effect for the magnetism to kill and minimize mite populations. Reduction percentages show that magnetized distilled water led to reduction $42.29 \%$, while the normal sea water $(S)$ recorded $46.66 \%$ and the magnetized sea water $(S+m a g)$ raised to $68.13 \%$. This means it was nearby value to the vertimec acaricide, which recorded $84.59 \%$, and increased to $86.63 \%$ with the magnetic field.

Results indicated that magnetic treatments with sea water significantly minimized the laid eggs as the distilled water (W) recorded 59.68 eggs/disc, which was decreased to 20, 7.91 eggs/disc for the treatments of sea water $(S)$ and magnetized sea water $(S+$ mag) respectively, that makes this treatments $(S+m a g)$ is promising in the control programs of mites and being a safe acaricide alternative.
\end{abstract}

Key words: Magnetism, Pest control, Tetranychus urticae, mites.

\section{INTRODUCTION}

No doubt in presence a whole natural magnetic field for the earth, and it influences everywhere, whether macro and / or microenvironments affecting all living organisms even in lab-under experimental conditions.

The different negative side effects for the recent technologies of 21 centaury e.g. forests of various kinds of waves represents the main challenges to plants, animals and human being.

Balmori. A. (2015) reported that the rate of scientific activity regarding the effects of anthropogenic electromagnetic radiation in the radiofrequency $(\mathrm{RF})$ range on animals and plants has been small despite the fact that this topic is relevant to the fields of experimental biology, ecology and conservation due to its remarkable expansion over the past 20 years. Current evidence indicates that exposure at levels that are found in the environment (in urban areas and near base stations) may particularly alter the receptor organs to orient in the magnetic field of the earth. These results could have important implications for some insects, especially in urban areas, but could also apply to some insects in natural and protected areas where there are powerful base station emitters of radiofrequencies. Therefore, more research on the effects of electromagnetic radiation in nature is needed to investigate this emerging threat.

In China, Li Jian Quan et al. (2005) studied the potential of electromagnetism technology as a physical control method 
against some pests e.g. ants and cockroaches. They reported: this method is better because it does not cause pollution and residues and it is also economic and safe.

Omoya and Kelly (2014) in their studies exposed 2 species of entomopathogenic bacteria isolated from termites to varying intensities of magnetic field for different periods of time. The two species of bacteria Bacillus subtilis and Serratia marcescens were able to induce morbid effects on termites. It was recorded that no reduction in the entomopathogenic potency of the bacteria after re-infection results. It was recommended to use these bacteria in certain formulation either powdery forms or suspensions to apply the infested wood or wood products.

Idriss et al. (2013) in their research for controlling the cotton white fly Bemisia tabaci under green house condition in Egypt tested combination of 3 factors: (1) colour of traps. (2) plant traps and (3) geomagnetic field.

Relationship of each factor with the horizontal flight behavior of $B$. tabaci was recorded. In respect of geomagnetic factor they found that $53.1 \%$ of $B$. tabaci adults were significantly attracted to the south-east direction. In addition that, the combined effect of the 3 factors, it was reported that when yellow sticky sheets and Sonchus oleraceus $\mathrm{L}$, as a wild trap plant (Sow thistle) were directed towards the south-east direction, the numbers of $B$. tabaci infested tomato were dramatically reduced from $8.1 \pm 0.13$ to $0.57 \pm 0.05$ adults $/ \mathrm{cm}$ within a week.

This current research aims to increase the ability of magnetized sea water to kill the two-spotted spider mite Tetranychus urticae Koch through safe physical method e.g. magnetic technology to achieve new acaricide alternative.

\section{MATERIAL AND METHODS}

Three similar glasses bottles ( 1 liter volume) were filled with: 1- distilled water 2sea Saline salt water and 3- vertimec solution (40 cm3/ $100 \mathrm{~L}$ water) respectively. Fifty-four 54 of similar size, small $(1.5 \mathrm{~cm})$ static magnetic were fixed around the external glass wall of each bottle.

Another 3 bottles with the same volume were filled with the same pre-mentioned solutions without any magnetic pieces and kept in the laboratory with enough far distance ( 2 meter). These three bottles were used as a comparison (control) for the main 3 bottles with the magnetic field.

The magnetic flux in the middle center of the main three bottles was measured with the tesla-meter apparatus in faculty of Engineering - Menoufia University. The magnetic field recorded 14-18 milli-tesla (ml.t).

As the vertimec (Abamectin 1.8\%) is a recommended acaricide to control the two spotted - spider mite Tetranychus-urticae Koch. with (40 ml/100 L water), it was chosen in the experiments against the mites individuals which used for bio-assay the effect of the 3 pre-mentioned magnetized solutions, with a comparison with their effect without exposure to the magnetic field.

Dipping technique was used as discs were dipped in the 3 investigated solutions (1- distilled water, 2- sea saline salt water and 3 - vertimec solution) and fixed on wetted cotton in Petri-dishes. Ten adult individuals of mites ( 6 males and 4 females) were kept on each botanical disc.

A completely randomized experiment with 3 replicates was conducted in laboratory to follow the number of dead individuals 1, 3 and 5 days after treatment.

Also, the number of total deposited eggs after 5 days was recorded.

Results were arranged in 3 tables and 1 figure.

Death corrected ratio was computed 1, 3 and 5 days after treatment according to Abbott's formula : 
Death corrected ratio $\%=$

$$
\left(1-\frac{n \text { in } T . \text { after treatment }}{n \text { in Co. after treatment }} \times 100\right)
$$

Where $: n$ in T. : Number of living individuals after dipping in the magnetized sea water

$\mathrm{n}$ in Co. : Number of living individuals after dipping in the normal sea water

\section{RESULTS AND DISCUSSION}

Results in Table (1) and figure (1) show the effect of distilled water (w) on the survivability of the mites. This treatment was considered as (the control) of the whole experiment. A total of 730 mite individuals (on 73 discs) were divided into 608 living and 122 dead individuals, with an average ratio (8.23 and 1.77), survival and dead individuals respectively for the disc.

Also, results in Table (1) show that, the use of magnetized distilled water led to increasing the dead mite individuals. Taking in consideration the 2 pre-mentioned figures of living and dead ratio for the control (distilled water), (w), (8.23 and 1.77) / 1 disc. Abbott's formula (1925) indicated that the effect of magnetized distilled water (W+ mag) decreased the mite population with $42.29 \%$.

In respect of oviposition availability, the same Table (1), indicated that, the magnetized distilled water ( $\mathrm{W}_{+}$mag) minimized numbers of oviposited eggs/disc from 59.68 eggs/disc in control (w) to only $37.61 \mathrm{eggs} / \mathrm{disc}$ for the magnetized water treatment. That seems to be beneficial in the field of plant protection. Fatma (2014) Egg hatchability percentage, incubation period, life cycle, longevity, life span, survivability, mean number of eggs/ female and sex ratio of the $1^{\text {st }}$ generation. Results showed that there was a linear negative relationship between the force of magnetic field and the percentage of egg hatchability. Hatching eggs were deceased from $100 \%$ in he check to $90.3 \%$ in 6 magnet unit's treatment. Also mean number of eggs and longevity deceased from 4.0 eggs \& 16.9 days to 2.3 eggs \& 1.4 days; while incubation period and life cycle were prolonged depending on the number of magnetic pieces from 7.0 \& 15.7 days to 8.412 .0 days, respectively.

Table (1): Number of eggs and rate of reduction (RR\%) in distilled magnetized and distilled water

\begin{tabular}{|c|c|c|c|c|c|c|c|c|}
\hline \multirow{2}{*}{$\begin{array}{l}\text { Period of } \\
\text { investigation }\end{array}$} & \multirow{2}{*}{ treatment } & \multirow{2}{*}{$\begin{array}{l}\text { No. of } \\
\text { discs }\end{array}$} & \multicolumn{2}{|c|}{ Total mites } & \multicolumn{2}{|c|}{ Mites/disc } & \multirow{2}{*}{$\begin{array}{c}\text { No. of } \\
\text { eggs/ } \\
\text { disc }\end{array}$} & \multirow{2}{*}{$\begin{array}{l}\mathrm{RR} \% \\
\text { Abbott } \\
\text { formula }\end{array}$} \\
\hline & & & live & dead & live & dead & & \\
\hline \multirow[t]{2}{*}{ Mar.-May 2015} & D.water (W) & 9 & 72 & 18 & 8 & 2 & - & - \\
\hline & W+ mag & 9 & 49 & 41 & 5.44 & 4.56 & 25.11 & $33.90 \%$ \\
\hline \multirow[t]{2}{*}{ Jun.-Aug. 2015} & D.water (W) & 27 & 221 & 49 & 8.14 & 1.81 & 66.3 & - \\
\hline & W+ mag & 18 & 73 & 107 & 4.06 & 5.94 & 50.11 & $50.67 \%$ \\
\hline \multirow[t]{2}{*}{ Sep. Jan. 2016} & D.water (W) & 37 & 315 & 55 & 8.51 & 1.49 & 53.06 & - \\
\hline & $\mathrm{W}+\mathrm{mag}$ & - & - & - & - & - & - & - \\
\hline \multirow{2}{*}{ Total } & D.water (W) & 73 & 608 & 122 & - & - & - & - \\
\hline & W+ mag & 27 & 122 & 148 & - & - & - & - \\
\hline \multirow{2}{*}{ Mean } & D.water (W) & - & - & - & 8.23 & 1.77 & 59.68 & - \\
\hline & $\mathrm{W}+\mathrm{mag}$ & - & - & - & 4.75 & 5.25 & 37.61 & $42.29 \%$ \\
\hline
\end{tabular}


Hussein, et al.,

Results of Table (2) and figure (1) show the effect of sea water (S), on the survivability of mites. A total of 530 individuals, when reared on 53 disc plants and dipped in the normal sea water were divided into 323 dead and 227 survival individuals. Abbott's formula (1925) declared that the average reduction value for the mite population by the normal sea water was $46.66 \%$

To study the effect of magnetized sea water (S+magnetic) on survivability of mites, a total of 640 mite individuals (on 64 discs) were investigated. Results (Table 2) show that suppression of mites reached to $68.13 \%$ as the total dead numbers of mites were 472 in comparison with only 168 living individual numbers.

Results, also indicated that average oviposited eggs per disc was clearly and significantly affected by the magnetized sea water $(S+\mathrm{mg})$. Figures showed that the normal sea water treatment(s) recorded 20 eggs/disc, while it was only 7.91 eggs/disc for the magnetized sea water $(\mathrm{S}+\mathrm{mag})$.
That seas to be beneficial and promising to compact mites in different crops.

Hussein et. al. (2014) Showed that there was a linear negative relationship between the force of the magnetic field and the hatchability percentage in Sitotroga cerralella $s$ hatching eggs decreased from $90 \%$ in the control to $22 \%$ with the magnetic field. Also it was reported that hatchability of eggs of Trichogramma evanescens decreased from $8231 \%$ to $47.06 \%$. This ratio recorded decrease in eggs of Spodoptera littoralis from $95.20 \%$ to $56.80 \%$ and for Spodoptera exiuga from $90 \%$ to $50.86 \%$.

Results of Table (3) and figure (1) indicated the effect of (abamectin 3.6) or (vertimec) pesticide, the main recommended pesticide against mites. This treatment, (v) was considered a certain concept for the (control) or (check) in the experiments.

Results showed that vertimec acaricide (v), suppressed the mite population with $84.59 \%$.

Table (2): Number of eggs and rate of reduction ( $R R \%)$ in sea water and magnetized sea water

\begin{tabular}{|c|c|c|c|c|c|c|c|c|}
\hline \multirow{2}{*}{$\begin{array}{c}\text { Period of } \\
\text { investigation }\end{array}$} & \multirow{2}{*}{ Treatment } & \multirow{2}{*}{$\begin{array}{l}\text { No. } \\
\text { discs }\end{array}$} & \multicolumn{2}{|c|}{ Total mites } & \multicolumn{2}{|c|}{ Mites/disc } & \multirow{2}{*}{$\begin{array}{c}\text { No. of } \\
\text { eggs/ } \\
\text { disc }\end{array}$} & \multirow{2}{*}{$\begin{array}{l}\mathrm{RR} \% \\
\text { Abbott' } \\
\text { formula }\end{array}$} \\
\hline & & & live & dead & live & dead & & \\
\hline \multirow{2}{*}{ Mar.-May 2015} & Sea water(S) & 9 & 52 & 38 & 5.78 & 4.22 & 19.33 & 29.77 \\
\hline & S+ mag & 18 & 37 & 143 & 2.06 & 7.94 & 8.94 & 74.97 \\
\hline \multirow{2}{*}{ Jun.-Aug. 2015} & Sea water & 9 & 29 & 61 & 3.22 & 6.78 & 28 & 60.87 \\
\hline & $\mathrm{S}+\mathrm{mag}$ & 9 & 27 & 63 & 3.0 & 7 & 6.67 & 63.55 \\
\hline \multirow{2}{*}{ Sep2015 Jan2016 } & Sea water & 35 & 146 & 224 & 4.17 & 5.83 & 12.69 & 49.33 \\
\hline & $\mathrm{S}+\mathrm{mag}$ & 37 & 104 & 266 & 2.18 & 7.19 & 8.13 & 65.86 \\
\hline \multirow{2}{*}{ Total } & Sea water & 53 & 227 & 323 & - & - & - & - \\
\hline & $\mathrm{S}+\mathrm{mag}$ & 46 & 168 & 472 & - & - & - & - \\
\hline \multirow{2}{*}{ Mean } & Sea water & - & - & - & 4.39 & 5.61 & 20 & 46.66 \\
\hline & S+ mag & - & - & - & 2.62 & 7.38 & 7.91 & 68.13 \\
\hline
\end{tabular}


Table (3): Number of eggs and rate of reduction (RR\%) in vertimec solution or magnetized vertimec solution

\begin{tabular}{|c|c|c|c|c|c|c|c|c|}
\hline \multirow{2}{*}{$\begin{array}{c}\text { investigation } \\
\text { dates }\end{array}$} & \multirow{2}{*}{ treatment } & \multirow{2}{*}{$\begin{array}{l}\text { No. of } \\
\text { discs }\end{array}$} & \multicolumn{2}{|c|}{ Total mites } & \multicolumn{2}{|c|}{ Mites/disc } & \multirow{2}{*}{$\begin{array}{l}\text { No. } \\
\text { eggs/ } \\
\text { disc }\end{array}$} & \multirow{2}{*}{$\begin{array}{c}\text { RR\% } \\
\text { Abbott } \\
\text { formula }\end{array}$} \\
\hline & & & live & dead & live & dead & & \\
\hline \multirow{2}{*}{1 Nov.2015 } & Vertimec (V) & 2 & 6 & 14 & 3 & 7 & 6 & 63.55 \\
\hline & $\mathrm{V}+\mathrm{mag}$ & 2 & 5 & 15 & 2.5 & 7.5 & 4.5 & 69.62 \\
\hline \multirow{2}{*}{10 Nov.2015 } & Vertimec & 2 & 0 & 20 & 0 & 10 & 0 & 100.0 \\
\hline & $\mathrm{V}+\mathrm{mag}$ & 2 & 0 & 20 & 0 & 10 & 0 & 100.0 \\
\hline \multirow{2}{*}{16 Nov.2015 } & Vertimec & 2 & 0 & 20 & 0 & 10 & 0 & 100.0 \\
\hline & $\mathrm{V}+\mathrm{mag}$ & 2 & 0 & 20 & 0 & 10 & 0 & 100.0 \\
\hline \multirow{2}{*}{23 Nov.2015 } & Vertimec & 3 & 2 & 28 & 0.67 & 9.33 & 0 & 91.86 \\
\hline & $\mathrm{V}+\mathrm{mag}$ & 3 & 6 & 24 & 2 & 8 & 0 & 75.70 \\
\hline \multirow{2}{*}{12 Dec. 2015} & Vertimec & 3 & 8 & 22 & 2.67 & 7.33 & 3 & 67.56 \\
\hline & $\mathrm{V}+\mathrm{mag}$ & 3 & 3 & 27 & 1 & 9 & 0.67 & 87.85 \\
\hline \multirow{2}{*}{ Total } & Vertimec & 12 & 16 & 104 & - & - & - & - \\
\hline & $\mathrm{V}+\mathrm{mag}$ & 12 & 14 & 106 & - & - & - & - \\
\hline \multirow{2}{*}{ Mean } & Vertimec & - & - & - & 1.27 & 8.73 & 1.8 & 84.59 \\
\hline & $V+m a g$ & - & - & - & 1.1 & 8.9 & 1.03 & 86.63 \\
\hline
\end{tabular}

The same Table (3), showed that magnetized vertimec pesticide solution $(\mathrm{V}+\mathrm{mag})$ was stimulated and its effect on the mites was increased as suppression reached to $86.63 \%$

Also, numbers of eggs under the both treatments $(\mathrm{V})$ and $(\mathrm{V}+\mathrm{mag})$ were tabulated recording 1.80 and 1.03 eggs/desk respectively. That means magnetism led to minimizing to some extent eggs oviposition in addition to increasing the effect of pesticide.

Basalova et al. (2016) reported that the response to magnetic fields (MFs) in some insects e.g. cockroaches is depending on photosensitive Cryptochromes (cry) and directly affect the visual system through the gene function.

Gegear et al. (2010) reported that understanding biophysical basis of animal magneto-reception has been one of the greatest challenges in sensory biology. They also, emphasized that magneto-reception system in some insects e.g. Drosophila melanogaster works through very fine mechanism depending on some factors e.g. light photoreceptors and certain wave length e.g. ultraviolet (uv) and blue light with below $420 \mathrm{~nm}$ wave length. 
Hussein et al (2015) investigated the effect of magnetic field on the physiological aspects of some insects, larvae of three insects were reared in laboratory in a suitable rearing boxes. The three insects were: cotton leaf warm, Spodoptera littoralis, red palm weevil, Rhynchophorus ferruginous and the greater wax moth, Galleria mellonella. Rearing insects started with a suitable larval instar. Numbers of larvae (form each insect) divided into 2 similar and equal groups, the first reared as a control (without magnetic field), while the second group was exposed to the magnetic field, (MF) along rearing periods. An appropriate numbers of larvae from the control and the treated ones were taken for Bio-chemical analysis. The measured physiological parameters were: total protein, total carbohydrates, total lipids, invertase enzyme and alkaline phosphatase. Results showed that each of body weight and growth rate as well as the physiological aspects were affected with the magnetic field. Rate of growth was negatively affected as it decreased in cotton leaf worm and red palm weevil. Results also demonstrated that invertase enzyme decreased in the treated larvae of $S$. littoralis and $G$. mellonella with $40.15 \%$ and $28.33 \%$ respectively lower than the control. In the same time, magnetic field led to increase the invertase enzyme in R. ferruginous with $71.6 \%$ higher than the control samples.

Results illustrated in Figure (1) show a linear negative relationship between the number of eggs and the magnetic field power. Also It indicates the positive relationship between suppression of mites populations and the power of magnetism.

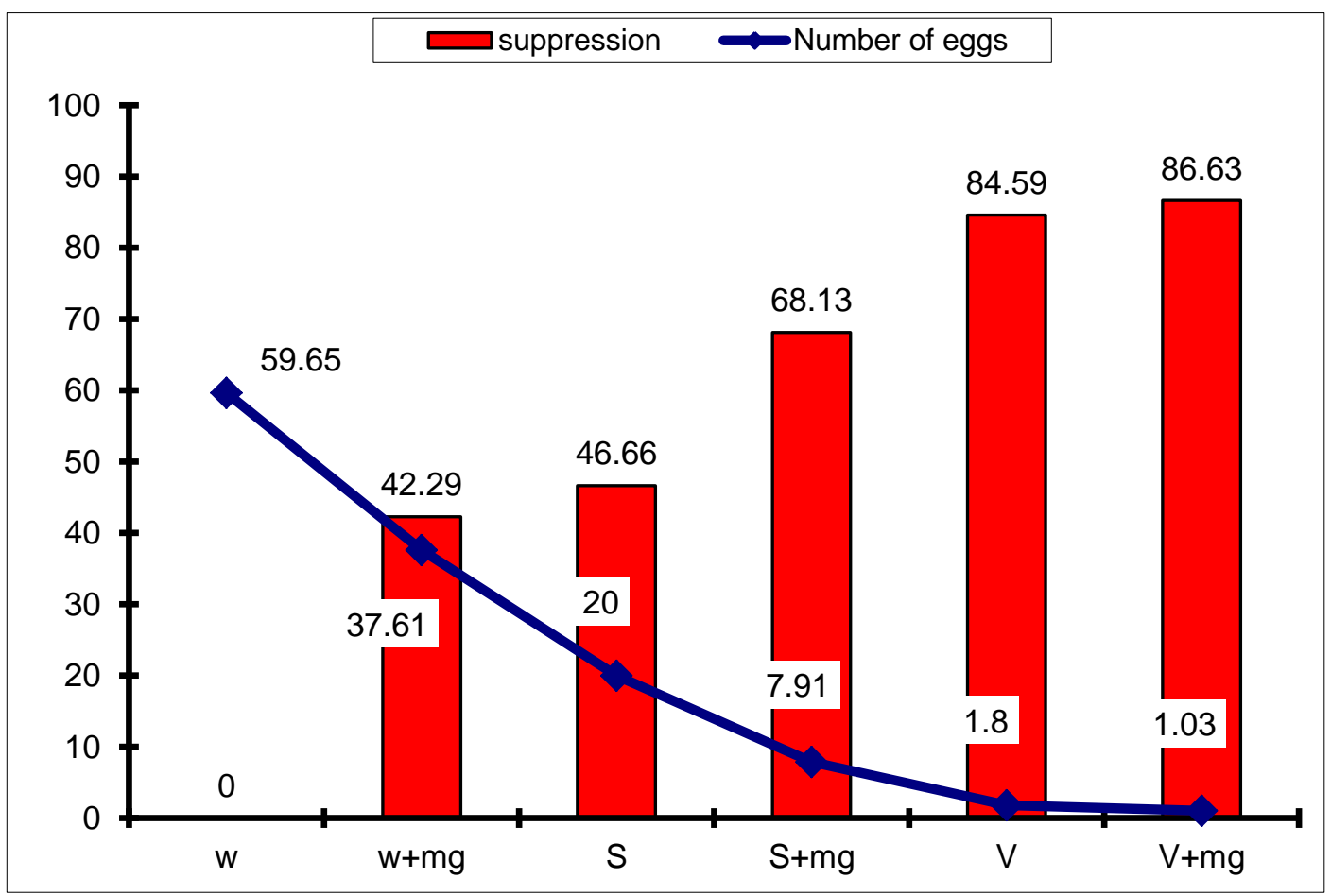

Figure (1): Number of eggs and ability to kill mites (Abbott's 1925) in different investigated treatments 


\section{REFERENCES}

Abbott, W. S. (1925). A method of computing the effectiveness of an insecticide. J. Econ. Entomol.; 18: 265267.

Balmori. A. (2015). Anthropogenic radiofrequency electromagnetic fields as an emerging threat to wildlife orientation, UK, Oxford, Science of the Total Environment; 2015. 518/519:58-60.

Bazalova, O., M. Kvicalova, T. Valkova, P. Slaby, P. Bartos, R. Netusil, K. Tomanova, P. Braeunig, Lee HowJing, L. Sauman, M. Damulewicz, J. Provaznik, R. Pokorny, D. Dolezel and M. Vacha (2016). Cryptochrome 2 mediates directional magneto-reception in cockroaches. Proceedings of the National Academy of Sciences of the United States of America; 2016. 113(6): 1660-1665.

Fatma, S. Ali, A. M. Hussein and K. E. Rady (2014). Interaction of Static Magneticnetic Fields (SMF) with Biology of Tetranychus urticae Kock (Acari). Acarines, 8(2): 39-43, 2014.

Gegear, Robert J. 1; Foley, Lauren E. 1; Casselman, Amy 1 and Reppert, Steven M. 1 (2010). Animal cryptochromes mediae magneto-reception by an unconventional photochemical mechanism. [Letter], Nature. 43(7282): 804-807.
Hussein, A. M., A.M. Hatem, M.K. Abbas, Ghada E. Abdalla, K.E. Rady, Salwa S.M. Abdel-Samad and M.A. Eweis (2015). Effect of Magnetic field on metabolism and enzyme activity in some harmful insects. Minufiya J. Agric. Res. Vol.40 No. 4(1): 999-1009.

Hussein, A.M., M.A. Eweis, Salwa S.M. Abdel-Samad and A.E. Hatem (2014), Potential benefits for utilization magnetism in plant protection. Minufiya J. Agric. Res. Vol.39 No. 1(2): 327-338.

Idriss, M. H., F. A. El-Meniawi, L. A. Rawash and A. M. Soliman (2013). The earth's geomagnetic field: a new approach for controlling the cotton whitefly Bemisia tabaci (Gennadius) Hemiptera: Sternorrhyncha: Aleyrodideae) in Egypt. Research Journal of Agriculture and Biological Sciences; 9(5): 223-231.

Li JianQuan, Hou JianJun, Shen ZuoRui, Zeng XiaoPeng (2005). Prospect of electro magnetism technology in hygiene pest control. Acta Parasitologica et Medica Entomologica Sinica; 12(2): 119127.

Omoya, F. O. and B.A. Kelly (2014). Variability of the potency of some selected entomopathogenic bacteria (Bacillus spp. and Serratia spp.) on termites, Macrotermes bellicosus (Isoptera: Termitidae) after exposure to magnetic fields., UK, International Journal of Tropical Insect Science; 34(2): 98-105. 


\section{ماذا عن إمكانية إستخدام ماء البحر الممغنط كأحد بدائل المبيدات الأكاروسية؟}

عبد الخالق محمد حسين ، غادة السيد عبد الله ، مريم جرجس حبشي ، أمل السيد معروف ،

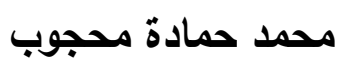

معهذ بحوث وقاية النباتات - مركز البحوث الزراعية - الدقى - الجيزة

الملخص العربى

في تجربة معطلية موسعة استمرت من مارس 2015م حتى يناير 2016م بهدف استيضاح تأثير المغناطيسية الاستاتيكية

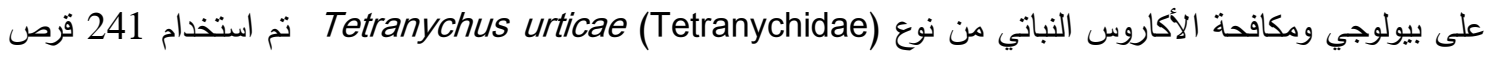

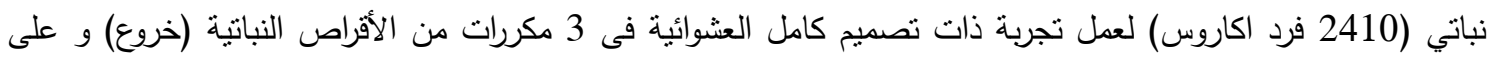

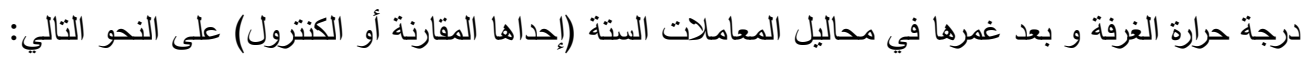

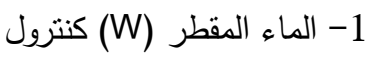

2- الماء المقطر الميغنط (W+ mag)

3- ماء البحر العادي (S)

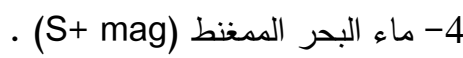

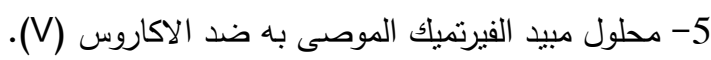

6- محلول مبيد الفيرتيكيك الممغنط (V+ mag) .

وبمتابعة الفحص و تسجيل النتائج بعد 1، 3، 5 يوم من المعاملة اتضح التأثثر الواضح للمغناطيسية فى موت وتقليل

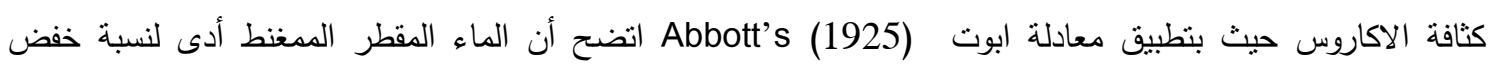

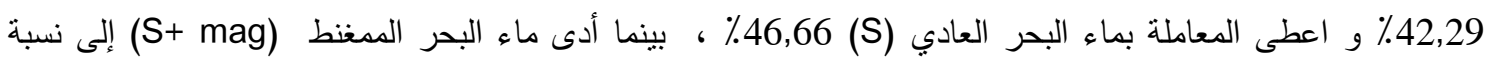

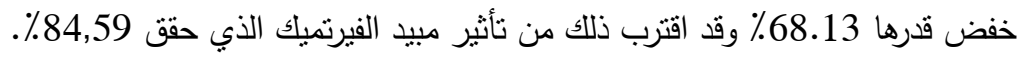

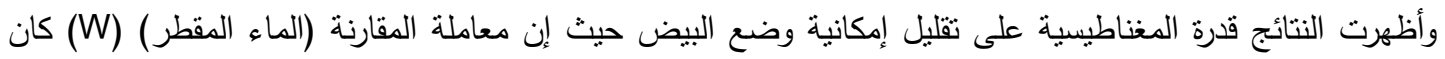

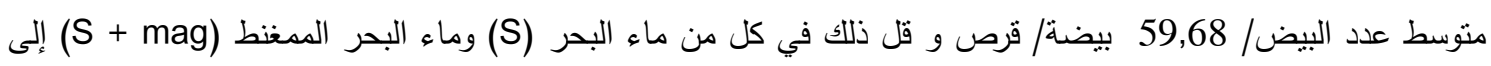
20، 7,91 بيضة/ قرص على النزتيب.

وهذه النتائج نجعل ماء البحر الممغنط (S + mag) معاملة واعدة لنقليل كثافة الأكاروس النباتي على المحاصيل الزراعية لتكون أحد بدائل المبيدات الأكاروسية الآمنة. 